Archived version from NCDOCKS Institutional Repository http://libres.uncg.edu/ir/asu/

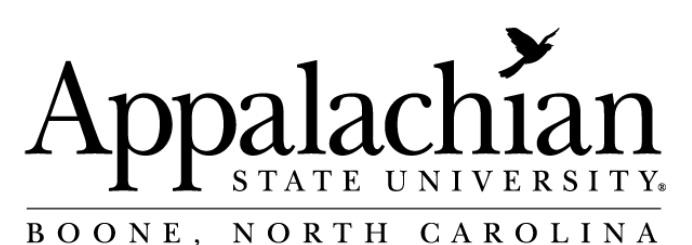

B O O N E, N O R T H C A R O L I N A

\title{
Effects Of Information Literacy Skills On Student Writing And Course Performance
}

\section{By: Xiaorong Shao and Geraldine Purpur}

\begin{abstract}
This study documents the information literacy skills of college freshmen at a mid-size comprehensive university. It also examines the association between students' information literacy skills and their writing abilities as well as their overall performance in a class. A major finding of the study is that information literacy skills were positively correlated with both student writing scores and final course grades. The findings of this study call for well-integrated library instruction programs and services to improve student information literacy skills.
\end{abstract}

Shao, X. and G. Purpur (2016). "Effects of Information Literacy Skills on Student Writing and Course Performance." The Journal of Academic Librarianship 42(6): 670-678. https://doi.org/10.1016/j.acalib.2016.08.006. Publisher version of record available at: https://www.sciencedirect.com/science/article/pii/S0099133316301756 


\title{
Effects of Information Literacy Skills on Student Writing and Course Performance
}

\author{
Xiaorong Shao ${ }^{\mathrm{a}}{ }_{\star}$, Geraldine Purpur ${ }^{\mathrm{b}}$ \\ a Appalachian State University, 218 College Street, ASU P.O. Box 32026, Boone, NC 28608, USA \\ b 218 College Street, ASU P.O. Box 32026, Boone, NC 28608, USA
}

Keywords:

Information literacy skills

Writing skills

Course grades

Academic performance

\section{a b s t r a c t}

This study documents the information literacy skills of college freshmen at a mid-size comprehensive university. It also examines the association between students'information literacy skills and their writing abilities as well as their overall performance in a class. A major finding of the study is that information literacy skills were positively correlated with both student writing scores and final course grades. The findings of this study call for wellintegrated library instruction programs and services to improvestudentinformation literacy skills.

\section{INTRODUCTION}

Developing student critical thinking skills has become essential to the mission of institutions of higher education as employers look for those skills in their new hires. One of the key findings from a national survey of business and nonprofit leaders by the Association of American Colleges and Universities (AAC\&U) was 93\% of surveyed employers would like their future employees to demonstrate critical thinking, communication and complex problem solving skills, and the business leaders considered these skills more important than a student's major (AAC\&U, 2013).

Information literacy (IL) and critical thinking are higher-order intellectual skills required for academic, professional and personal development and success. These two sets of skills share common goals and intersect in many areas. Information literacy includes the ability to locate information, evaluate and use it effectively whereas critical thinking involves the process of exploring and evaluating ideas in order to make a decision or form an opinion on a topic or problem (Wertz et al., 2013). Doyle (1994) stated that "while critical thinking skills provide the theoretical basis for the process, information literacy provides the skills for practical, real world application."

In addition, two similar studies conducted by librarians and faculty members at Oregon State University and Purdue University, suggested

\footnotetext{
* Corresponding author.

E-mail addresses: shaox@appstate.edu (X. Shao), purpurgm@appstate.edu (G. Purpur).
}

the strong connections between information literacy and critical thinking and writing skills (Deitering \& Jameson, 2008; Wertz et al., 2013).

In response to a major priority of the University of North Carolina (UNC) System's five-year strategic plan, "Our Time, Our Future: The UNC Compact with North Carolina," the UNCGeneral Education Council was formed in 2013 and charged with developing general education goals and assessment tools for system's 16 higher education institutions. Two core competencies, critical thinking and written communication skills, were recommended as system-wide fundamental requirements for successful mastery in all academic disciplines (Ortega \& Stewart, 2014).

To facilitate the implementation of general education goals and the two core competencies, librarians at Appalachian State University (Appalachian) in North Carolina began seeking ways to improve student information literacy skills and started working with teaching faculty members to assess these skills. Examining the relationship between information literacy skills and student academic performance was one of manyinitiativeslibrarians undertook.

During the spring and fall semesters in 2014, librarians at Appalachian conducted a study to document freshmen information literacy skills. The premise of this study is that information literacy skills, as part of critical thinking skills, can be learned through library instruction sessions and when students utilize library resources and services. The findings of this study will help librarians better understand the correlation between student information literacy skills, writing abilities and course grades. The ultimate goal of the study was to improve 
information literacy instruction and library services in order to align library teaching and services more closely with the UNC General Education goals for developing student critical thinking and written communication skills.

This information literacy skills study follows new directions of higher education reforms, which emphasize teaching for understanding and critical thinking rather than information imparting. Librarians have been seeking new ways to help their institution strengthen academic quality, improve access, and increase retention and graduation rates.

\section{LITERATURE REVIEW}

In the Framework for Information Literacy for Higher Education by the Association of College and Research Libraries (ACRL), information literacy is defined as "the set of integrated abilities encompassing the reflective discovery of information, the understanding of how information is produced and valued, and the use of information in creating new knowledge and participating ethically in communities of learning" (ACRL, 2015). The ACRL Information Literacy Competency Standards for Higher Education indicated that information literacy competency expands learning beyond formal classroom settings and provides individuals with self-directed investigations as they move into internships, professional positions, and growing responsibilities in all aspects of life. Information literacy forms the basis for lifelong learning, which is essential to the mission of higher education institutions (ACRL, 2000). Information literacy helps develop individuals' intellectual abilities of reasoning and critical thinking and enables them to learn how to learn (ACRL, 2006).

The International Federation of Library Associations and Institutions (IFLA)'s Guidelines on informational literacy for lifelong learning, asserts that information literacy skills are key competencies in lifelong learning. They are the first step toward achieving educational goals. The development of such skills should take place throughout citizens' lives, and especially during their formative years, when librarians, as part of the learning community and as experts in information management, should assume the key role of facilitating information literacy (Lau, 2006).

By all accounts, becoming information literate is important for individuals to succeed both academically and professionally. In a report entitled What matters to student success: A review of the literature, Kuh, Kinzie, Buckley, Bridges, and Kayek (2006) suggested that information literacy is one of the emerging indicators for student success.

The major issue for librarians, however, is to empirically assess the impact of information literacy skills on student success. In this context, the following literature review looks briefly at the methods of assessing information literacy skills and their attempts to gauge the impact of information literacy skills on student academic success in institutions of higher education.

\section{INFORMATION LITERACY ASSESSMENT}

Several studies indicated that writing portfolios and research paper bibliographies are useful tools to evaluate students' information literacy learning outcomes. The bibliographies proved to be a good representation of student work because they are reliable and understandable to both librarians and teaching faculty. Knight (2006) and Samson (2010) from two different academic libraries, used grading rubrics, which was developed based on the course learning objectives and the ACRL Information Literacy Competency Standards, to evaluate and score the research bibliographies to reflect the student's level of information literacy.

Scharf, Elliot, Huey, Briller, and Joshi (2007) found a high correlation between the writing scores and information literacy scores, resulting from a writing portfolio study of graduating seniors at the New Jersey Institute of Technology. In addition, a writing project which incorporating information literacy components by White-Farnham and Gardner
(2014) at the University of Wisconsin-Superior, showed an improvement in both student writing and information literacy.

\section{EFFECTS OF INFORMATION LITERACY INSTRUCTION ON GPAS AND RETENTION RATES}

Several recent studies focusing on the impact of information literacy on the academic performance of students indicated that information literacy instruction and student information literacy skills were positively correlated with the student grade point averages (GPAs), retention and graduation rates.

Vance, Kirk, and Gardner (2012) at Middle Tennessee State University examined the relationship between formal library instruction and student retention rates and grade point average. Two years of student demographic data and library instruction records were used to correlate retention rates and grade point averages among first-year students. Data analysis showed that library instruction had no impact on student retention. However, a statistically significant result indicated that students who had received library instruction had a higher GPA than students who did not. The results imply the existence of positive influence of formal library instruction on student academic achievement.

A similar study took place at the University of Wyoming (BowlesTerry, 2012) where librarians used a mixed-method approach to determine whether a correlation existed between information literacy instruction and grade point average at graduation. Academic transcript analysis showed a significant relationship between upper-level library instruction and higher GPA at graduation. In a focus group interview, participants mentioned specific skills or resources learned in library instructions sessions were helpful for research assignments throughout their academic careers, supporting the premise that information literacy increases student success.

\section{EFFECTS OF LIBRARYUSESONSTUDENT PERFORMANCE}

Some studies also showed that the number of library services and resources students used was correlated with their GPAs and retention rates. Researchers at the University of Minnesota (Soria, Fransen, \& Nackerud, 2014) found a positive association between library uses (such as interlibrary loan service, number of check-outs, database access logins) and GPAs as well as student retention rate from first to second semesters. An interesting finding from a study conducted by Kot and Jones (2014) at Georgia State University Library, suggested that those who used library study rooms and attended research clinics had the largest utilization of the library resources, and therefore had a higher first-term GPA.

Zhong and Alexander (2007) and Cherry, Rollins, and Evans (2013) reported that those who utilized library services and resources (e.g., reference service, research assistance, database logins) more frequently had a higher GPA.

\section{COLLABORATION AMONG LIBRARIANS AND FACULTY}

A recurring theme in the literature regarding successful implementation of information literacy instruction and assessment is the importance of librarians and faculty working together. Knight (2006); Samson (2010), and Scharf et al. (2007) all reported that librarians and faculty jointly developed effective information literacy measurement tools, resulting in significant improvements in the delivery and systematic integration of information literacy skills into the curriculum. OtherexamplesincludeaninitiativeatCarleton College(Leebaw,Partlo, \& Tompkins, 2013), where librarians solicited the help of faculty in their information literacy in a student writing project or portfolio assessment project. Faculty provided input on the grading rubric design and participated as writing paper readers and graders. This cooperation resulted in a much deeper and richer assessment. This was also the case at Middlesex County College in New Jersey (Thompson, 2013) where 
librarians and faculty partnered to develop effective lessons incorporating information literacy and critical thinking as well as writing skills altogether. According to Thompson (2013), collaboration yielded improvements in the work of their students.

The literature review showed that the majority of the studies examined the relationship between information literacy skills and student academic success, which equates to better student retention rates and higher GPAs (Vance et al., 2012; Bowles-Terry, 2012; Soleymani, 2014). Many of the studies highlighted the benefits of using student work, such as annotated bibliographies and writing portfolios in the assessment process (Knight, 2006; Samson, 2010; Scharf et al., 2007; Leebaw et al., 2013). Another factor which emerged was the positive outcome resulting in the collaboration of librarians and faculty on information literacy assessments (White-Farnham \& Gardner, 2014; Knight, 2006; Samson, 2010; Scharf et al., 2007; Leebaw et al., 2013). Many of these collaborations between librarians and writing faculty, showed that integrating information literacy skills into writing assignments has proven to be an effective strategy for improving both skill sets. However, only a few studies specifically looked at the statistical correlation between information literacy and writing skills. A study conducted in 2007 by Scharf et al. revealed a major correlation between the writing scores and information literacy scores. Therefore, the need for further research in this area is warranted.

\section{PURPOSES AND OBJECTIVES}

The purpose of this study is to examine the association between student information literacy skills and their writing abilities as well as their overall performance in a class. The study's objectives are to:

- analyze the correlation between student information literacy skills and their writing skills;

- describe the association between student information literacy skills and their course grades;

- identify the most important information literacy skills affecting the student writing ability and overall performance;

- and assess the effect of library uses on student performance.

\section{PROCEDURES AND METHODS}

\section{POPULATIONOFTHESTUDY}

The population for this study included freshman students at Appalachian State University who were taking either basic English writing class (ENG1000) or First Year Seminar course UCO1200 (UCO stands for University College) during spring and fall semesters in 2014. Approximately 3000 freshmen were enrolled at Appalachian in $2014 . \mathrm{Li}^{-}$ brary instruction is a required component for all the First Year Seminars courses. Although it is not required, most of ENG1000 course instructors choose to have one-shot library instruction for their classes.

To ensure that UCO1200 classes meet General Education Outcomes, a set of common expectations has been developed which includes: "involving students in problem-based learning with a research/library component" (Appalachian State University, 2016). Although a writing assignment is not a requirement for UCO1200 courses, many of the UCO1200 instructors assign a research paper as the final project. The research and writing process is very similar to the ENG1000 classes. All of the UCO1200 classes included in this study required the students to write a research paper and meet the source and page-length criteria.

The UCO1200 and ENG1000 curricular are charged with supporting AppalachianState University's GeneralEducation Program Goals, which includes developing critical and analytical thinking skills and cultivating effective communication skills (writing, speaking, and visual). Additionally, information literacy skills are built into the assessment criteria for both of these General Education goals. Each student is required to take three General Education courses (i.e., nine credit hours).

\section{INFORMATION LITERACY SKILLS TEST DEVELOPMENT}

The information literacy skills test for this study was developed based on an extensive literature review, study of the 2000 ACRL information literacy standards, and the library research skills assessment surveys used for UCO1200 and ENG1000 during 2009-2013 period. The test included five parts: Research strategies (6 questions); Resource types (5 questions); Scholarly vs. popular (6 questions); Evaluating websites (3 questions); and Demographic information (3 questions). In addition, the test collected information about students' major and class levels during the spring 2014 semester. In fall semester 2014, two questions were added to the test: the number of library instruction sessions received and other library services (e.g. individual consultations, online tutorials, service desks, library research guides) students used in order to complete their writing assignments. All questions were multiple choice questions. See Appendix A for the information literacy skills test.

Thirty undergraduate students took the test in a pilot study early in each semester in 2014. Cronbach's alphas, measuring the internal consistency of the test questions, for four parts (Research strategies, $\mathrm{Re}^{-}$ source types, Scholarly vs. popular, Evaluating websites) were 0.974, $0.873,0.814$ and 0.871 respectively. Five librarians reviewed the test questions. Minor revisions were made to the questions based on the pilot study and librarians' feedback.

The information literacy skills test was posted online through SelectSurvey. The test was administered by librarians and instructors during regular class meeting times.

\section{SAMPLE OF THE STUDY AND WRITING ASSIGNMENTS}

During both spring and fall semesters 2014, librarians contacted the instructors teaching UCO1200 and ENG1000 and explained the purpose of the study. Ten classes met the criteria for the study in spring 2014. Seven classes decided to participate in the study. In fall semester 2014, 12 classes were able to participate in the study.

In this study, each participating class project must contain a minimal 5-page writing assignment that cites at least five sources. The sources cited must include one book, two scholarly articles, and two additional reliable and credible sources chosen by the students. All classes incorporate a variety of writing assignments which are geared toward developing critical thinking, reading, and writing skills, and one of them must focus on information research. Students are usually required to begin the process by finding background information on their topic using encyclopedias. The next step is to develop a thesis statement based on the answer to a question they have posed related to their topic. Students then search for books and media in the library catalog and articles in the library databases to support their thesis statement and arguments. They may also search the Internet for additional sources. In this study, participating classes requested students analyze the sources they found and compile an annotated bibliography. The annotations must include a summary, evaluation, and reflection. The information research parts were 20 to $30 \%$ of their final writing scores.

\section{DATA COLLECTION AND ANALYSIS}

The librarians involved in the study offered the same information literacy instruction for the participating classes that they do for other classes. The only difference for this study was that the librarians involved in the study administered the online information literacy skills test toward the end of the semester to allow students time to use other library services as they work on their writing assignments.

The information literacy skills test scores were collected from 398 students in 19 classes taught by eight instructors. The participating 
students' writing scores and their course scores were obtained through the course instructors. The weight of the writing scores in their final course grades ranged from $10 \%$ to $75 \%$.

Data were analyzed using the Statistical Package for Social Sciences (SPSS). Both descriptive and inferential statistics were employed to summarize the data.

\section{FINDINGS}

\section{DEMOGRAPHIC INFORMATION OF PARTICIPANTS}

In this study, 398 students from 19 classes completed the information literacy skills test during two semesters in 2014, of which 386 were freshmen and 12 were sophomores. The average information literacy score was 78.5 out of 100 points. The intended majors of participants were across the board, with $16.3 \%$ in social sciences, $13.6 \%$ in natural sciences, $10.3 \%$ in humanities, $23.6 \%$ in business, and $22.4 \%$ in health sciences. $13.8 \%$ students reported "undecided" on their majors.

\section{ASSOCIATION BETWEEN INFORMATION LITERACY TEST SCORES, WRITING SCORES, AND FINALGRADES}

The Pearson product-moment correlation coefficients were computed to examine the association between information literacy skills scores, writing assignment scores, and final course scores. The results indicated that information literacy scores were positively and strongly correlated with students' writing scores $(\mathrm{n}=344, \mathrm{r}=0.153, \mathrm{p}=0.004)$. In addition, theinformation literacy scores were positively related to students' final course scores $(n=345, r=0.112, p=0.037)$. The findings suggested that those who had higher information literacy scores tended to do better both in writing and their overall performance in a class. Table 1 presents the results of Pearson's correlation coefficients and descriptive statistics for information literacy scores, writing scores, and final course scores.

The Pearson product-moment correlation coefficient is a measure of the strength of the linear relationship between two variables. Pearson's $r$ value can range from -1 to 1 . An $r$ of -1 indicates a perfect negative linear relationship between variables, an $\mathrm{r}$ of 0 indicates no linear relationship between variables, and an $\mathrm{r}$ of 1 indicates a perfect positive linear relationship between variables (Lane, n.d.).

\section{EFFECTS OFDIFFERENTPARTSOFINFORMATIONLITERACY SKILLS}

The results of the Pearson's correlation coefficients between different information literacy skills sets and the student writing and final grades showed that the writing scores were strongly associated with the students' knowledge of "scholarly versus popular sources" ( $\mathrm{n}=$
$344, \mathrm{r}=0.145, \mathrm{p}=0.007)$. The final course scores were significantly correlated to two sets of information literacy skills: type of sources $(\mathrm{n}=345, \mathrm{r}=0.124, \mathrm{p}=0.021)$ and website evaluation $(\mathrm{n}=345$, $\mathrm{r}=0.117, \mathrm{p}=0.029)$.

\section{EFFECTSOFOTHERLIBRARYSERVICES}

An independent-samples $t$-test was conducted to examine whether or not using certain library service by students, such as, library research guides, online tutorials, research advisory program (RAP), library desk service (LDS) would have any effects on their information literacy scores, writing scores and final scores. There were no significant effects found between the variables. However, those who used a research advisory program and library desk service tended to have slightly higher information literacy scores, writing scores and final course scores than those who did not use the two services. See Table 2 for more information.

In addition, a one-way ANOVA was conducted to compare the effect of number of library instruction sessions attended by students on information literacy skills, writing and final course scores. The results indicated that the number of one-shot library instruction sessions was not significantly associated with students' information literacy skills [F (3, $267)=0.908, \mathrm{p}=0.437]$, writing scores $[\mathrm{F}(3,232)=0.706, \mathrm{p}=$ $0.549]$ and final course grades $[\mathrm{F}(3232)=1.426, \mathrm{p}=0.236]$.

It appears that the students who received more than one instruction session may become uninterested. Freshman students at Appalachian usually have two to three library instruction sessions from three required General Education courses they take.

\section{CONCLUSIONS}

The findings from this information literacy skills study validate those of previous similar studies and support that information literacy skills, which are part of critical thinking skills, can help improve student writing ability and academic performance. While most previous studies focused the effects of information literacy skills on indicators of student academic success, such as retention rates and GPAs, this study not only examines the association between students' information literacy skills and their course performance, but also the correlation between information literacy skills and writing abilities.

In addition, this study and other similar studies support that using library services and resources enhances student information literacy skills and thus their overall academic performance (Kot \& Jones, 2014; Soria et al., 2014; Zhong \& Alexander, 2007). Therefore, it is important for librarians to provide well-integrated library instruction programs and services to improve student information literacy skills.

Correlations and descriptive statistics of IL skills, writing scores and final grades

\begin{tabular}{|c|c|c|c|c|}
\hline & & Information literacy skills scores & Writing assignment scores & Final course scores \\
\hline \multirow[t]{3}{*}{ Information literacy skills scores } & Pearson correlation & - & $0.153^{\star \star}$ & $0.112^{*}$ \\
\hline & Sig. (2-tailed) & & 0.004 & 0.037 \\
\hline & $\mathrm{N}$ & 398 & 344 & 345 \\
\hline \multirow[t]{3}{*}{ Writing assignment scores } & Pearson correlation & $0.153^{\star *}$ & - & $0.367^{* *}$ \\
\hline & Sig. (2-tailed) & 0.004 & & 0.000 \\
\hline & $\mathrm{N}$ & 344 & 344 & 344 \\
\hline \multirow[t]{3}{*}{ Final course scores } & Pearson correlation & $0.112^{*}$ & $0.367^{* *}$ & - \\
\hline & Sig. (2-tailed) & 0.037 & 0.000 & \\
\hline & $\mathrm{N}$ & 345 & 344 & 345 \\
\hline Means & & 78.47 & 83.788 & 89.674 \\
\hline Standard deviation & & 11.996 & 14.3052 & 7.8389 \\
\hline
\end{tabular}


Table 2

Means and standard deviations (SD) of library desk service and research advisory program

\begin{tabular}{llllll}
\hline & \multicolumn{2}{l}{ Service } & N & Mean & SD \\
\hline Information literacy skills scores & \multirow{2}{*}{ LDS } & Did not use & 187 & 78.24 & 11.901 \\
& & Used & 84 & 78.43 & 11.736 \\
& \multirow{2}{*}{ RAP } & Did not use & 225 & 78.14 & 12.062 \\
Writing assignment scores & & Used & 46 & 78.95 & 10.712 \\
& \multirow{2}{*}{ LDS } & Did not sue & 164 & 85.11 & 9.2396 \\
& & Used & 72 & 86.60 & 7.9080 \\
Final course scores & \multirow{2}{*}{ RAP } & Did not use & 195 & 85.55 & 9.0404 \\
& & Used & 41 & 85.68 & 8.0779 \\
& \multirow{2}{*}{ LDS } & Did not use & 164 & 90.36 & 6.7304 \\
& \multirow{3}{*}{ RAP } & Used & 72 & 91.86 & 5.7295 \\
& & Did not use & 195 & 90.72 & 6.5796 \\
& & Used & 41 & 91.27 & 5.9565 \\
\hline
\end{tabular}

The study also provides an argument for librarians and faculty members to work together to maximize the benefits of teaching students information literacy skills in order to improve their written communication and academic performance. McCracken and Johnson (2015) at St. Edward's University have offered a good example in their pilot study that librarians and instructors can work collaboratively and successfully on incorporating new information literacy threshold concepts into information literacy sessions focusing on students writing projects. Through partnering with faculty to create curriculum-integrated programs, librarians can actively contribute to students' learning processes in their quest to enhance the skills, knowledge and attitudes needed to become lifelong learners (Lau, 2006).

Today's academic library, as a learning center on campus, does not just collect, preserve, and organize information. It also conducts teaching, research, and creates knowledge (ACRL, 2006). Furthermore, the academic library helps students develop transferable skills such as critical thinking and effective communication, which are much needed for their education and career. In this sense, the library has become an integral part of student learning, development, and success.

Dear Student,

Information Literacy Skills Test

This test is designed to help us improve our library instruction program and the resources and services we provide. The test only includes 25 questions and it should take less than 15 minutes. You are among 200 students completing the assessment.

If you have any questions, do not hesitate to contact us. Thank you for your participation.

Xiaorong Shao, Ph.D. Information Literacy Librarian/Associate Professor

Email: shaox@appstate.edu Phone: 828-262-7714

Geraldine Purpur, User Services Librarian/Senior Lecturer

Email: purpurgm@appstate.edu Phone: 828-262-6903

1.

Please type your name.

2.

a. Which of these broad areas contains your major?

b. Social Sciences

Natural Sciences

d. Humanities

e. Business

f. Health Sciences

Undecided

3.

a. What is your current class level?

b. Freshman

c. Sophomore

Junior

d. Senior

4.

a. How many library instruction sessions have you had?

1

b. 2

d. 3

more than 3 
5. library servicesyou have used In order to completeyour writing assignments (choose all that apply):

a. Individual consultation (e.g. RAP session)

b. Onlinetutorials

c. Libraryservice desks

d. Others (e.g. library guides, chat, phone, email,texting...)

6. When beginning library research,the FIRST step of creating a search strategys to:

a. Locatebooks using the library'sonlinecatalog

b. Search a librarydatabase forjournal articles

c. Analyze your topic to identify keywords or phrases

d. Locate a newspaper article on your topic

7. You are doing llbrary research for a 10-page argumentative research paper advocating pet therapy for the elderly. Which ofthefollowing is the MOSTLOGICALORDER inthe research process?

a. Locate books, conduct aweb search, follow leads from web sites, and brainstorm keywords.

b. Conduct a web search, locate subject encyclopedia(s), locate magazine articles, and locate books.

c. Locate scholarlyjournal articles, locate books, conduct aweb search, and followleads from sources.

d. Brainstorm keywords, conducta quickweb search,locate books, and locate scholarlyjournal articles.

8. Which of the following keyword examples may yield the best results for the statement below na library database search?

Statement: "Describe the effects of automobile emissions on air quality."

a. Automobileand effects

b. Automobile and emissionandair quality

c. Effects and emission and quality

d. Emissionandairquality

9. Which source would most kely provide you with objective and non-biased information for the main concepts in the following statement?

Statement: "Describe the effects of automobile emissions on air quality"

a. The latest annual report from a major automobile manufacturer

b. A study featured in a peer-reviewed journal

c. A personal interview with an influential lobbyist

d. A web site that advocates clean air

10. You searched for information usintthe terms world population AND rowth.f you add the term Clina toyour search,(world popmation AND 1rowth AND Clina) your search will yield:

a. Same results

b. More results

c. Less results

d. None of the above

11. Go to the library homepale to find the BOOK Men in Black by John Harvey. Which of the followings the correct call number for the book?

a. $\quad$ PN1997 ENGL .C87 1998

b. BF789.C7 H37 2013

c. PR149.C67 H37 1996

d. PN1997 ENGL.M457 2008 
12. Edwards,P. N. (2010). A vast mache: Computer models,climate data,and the politics of global warming.cambridge,Mass: MIT Press.

Which of the following best describes the above citation?
a. Journal article
b. Book
c. Chapter ina book
d. Web document

13. Chandrasekhar,SSorial,G.,\&Weaver,J.\{2006). Bpersant effectiveness on oil spills impact of sallnity. ICES Journal of Marine Science,63(8),118-1430.

Which of the following best describes the above citation?
a. Journal article
b. Book
c. Chapterina book
d. Web document

14. Blanchard,S. (2007): Polley analysts: Shaping society through research and problem-solving. USA.gov Retrieved from: http://www. bls.gov/opub/oog/2007/spring/art03.pdf

Which of the following best describes the above citation?
a. Journal article
b. Book
c. Chapter inabook
d. Web document

15. Gonzalez,V.(2012). Assessment of blllnguaVmultillngualPre-K-grade 12students: Acrltlcal discussion of past, present,and futureksues. Theoryhto Practice, 51(4), 290-296.

Which of the following best describes the above citation?
a. Journal article
b. Book
c. Book chapter
d. Web Document

16. Which of the following best describes an academic book?

a. Book does not include bibliographic references

b. Publisherisoftenauniversity press/publisher

c. Book iswritten for the general public

d. Author is a lay person, rather than a subject expert

17. Which of the following best describes a popular article?

a. Article is written by journal ists

b. Article is written by a subject specialist or expert inthe field

c. Article is peer-reviewed

d. Article iswritten for professors and students

18. Which of the following best describes a scholarly article?

a. Article is written in non-technical language

b. Article includes a bibliography or list of sources

c. Article is written for a general audience

d. Article often reports on current topics or events

19. $\quad$ s this artlcle scholarly or popular? Cilek on the citat on below to view the articleh a new window:

Ouellette, G.,\& Senechal,M. (2008). Pathways to literacy: a study of invented spelling and ts role in learning to read. Child Development,79(4), 899-913.
a. Scholarly
b. Popular 
20. Is this article scholarly or popular? Click on the citation below to view the article in a new window:

Paul, A. (2011). The Uses and Abuses of Optimism (and Pessimism). Psychology Today, 44(6), 56-63.

a. Scholarly

b. Popular

\section{Is this article scholarly or popular? Click on the citation to view the article in a new window:}

MacGillivray, L., Ardell, A., \& Curwen, M. (2010). Supporting the literacy development of children living in homeless shelters. Reading Teacher, 63(5), 384-392.
a. Scholarly
b. Popular

22.

a. Which of the following types of information does NOT need to be cited?

b. A quotation from the New York Times online

c. A photograph of Rosa Parks that you found from a Biography Dictionary

d. A paragraph you wrote summarizing information from a journal article A summary of your ideas on a research topic

\section{Who is the publisher of this site?}

Click on the following URL and view the website to answer questions \#23 and \#24:

http://www.healthmetricsandevaluation.org/

a. Department of Health and Human Services
b. Institute for Health Metrics and Evaluation
c. World Health Organization
d. Institute for Human Development

24.

a. Which of the following suggests that this is a reliable website?

b. The site contains data, statistics or other facts that you can check

c. The author or publisher is indicated

d. Sources of the research are given

e. Links are current

All of the above

f. b and d only

25.

a. Which of the following would you use to evaluate a webpage?

b. Accuracy. If a webpage is free of errors and provides reliable information...

b. Authority. If a webpage lists the author credentials, qualifications and contact information...

c. Objectivity. If a webpage is objective in presenting the information with limited advertising...

d. Currency. If a webpage is current and updated regularly...

e. All of the above

Note: Embedded links in Questions \#19, \#20, and \#21 are no longer showing in this Word document.

\section{REFERENCES}

Appalachian State University (2016). Teaching resources. Retrieved from http:// firstyearseminar.appstate.edu/teaching-resources.

Association of American Colleges and Universities (2013). Employers more interested in critical thinking and problem solving than college major. Retrieved from https:// www.aacu.org/press/press-releases/employers-more-interested-critical-thinkingand-problem-solving-college-major.

Association of College \& Research Libraries (2015). Framework for information literacy for higher education. Retrieved August 9, 2015 from http://www.ala.org/acrl/standards/ ilframework.

Association of College and Research Libraries (2000). Information literacy competency standards for higher education. Chicago: ACRL Retrieved from http://www.ala.org/ acrl/sites/ala.org.acrl/files/content/standards/standards.pdf.

Association of College and Research Libraries (2006). Changing roles of academic and research libraries. This essay derives from a Roundtable on Technology and Change in Academic
Libraries, convened by the Association of College and Research Libraries on November 23, 2006 in Chicago. Retrieved from http://www.ala.org/acrl/issues/value/changingroles. Bowles-Terry, M. (2012).Libraryinstruction and academicsuccess: A mixed-methods assessment of a library instruction program. Evidence Based Library and Information Practice, 7(1), 82-95.

Cherry, E., Rollins, S. H., \& Evans, T. (2013). Proving our worth: The impact of electronic resource usage on academic achievement. College \& Undergraduate Libraries, 20(34), 386-398 Retrieved from http://0-eds.a.ebscohost.com.wncln.wncln.org/eds/ pdfviewer/pdfviewer?sid=6f068685-bd1d-4f27-8199-16feff $7023 \mathrm{f} 7 \%$ 40 sessionmgr $4004 \&$ vid $=4 \&$ hid $=4105$.

Deitering, A., \& Jameson, S. (2008). Step by step through the scholarly conversation: A collaborative library/writing faculty project to embed information literacy and promote critical thinking in first year composition at Oregon State University. College and Undergraduate Libraries, 15(1/2), 57-79.

Doyle, C. (1994). Information literacy in an information society: A concept for the information age. Syracuse, NY: ERIC Clearinghouse on Information Resource ED372763 Retrieved from http://files.eric.ed.gov/fulltext/ED372763.pdf. 
Knight, L. A. (2006). Using rubrics to assess information literacy. Reference Services Review, 34(1), 43-55.

Kot, F. C., \& Jones, J. L. (2014). The impact of library resource utilization on undergraduate students' academic performance: A propensity score matching design. College and Research Libraries, crl14-616, 566-586 Retrieved from http://crl.acrl.org/content/76/ 5/566.full.pdf+html.

Kuh, G., Kinzie, J., Buckley, J. A., Bridges, B., \& Kayek, J. (2006). Whatmatters to studentsuccess: A review of the literature. Commissioned report for the National Symposium on Postsecondary Student Success: Spearheading a dialog on student success Retrieved from http://nces.ed.gov/npec/pdf/kuh_team_report.pdf.

Lane, D. M. (n.d.). Online statistics education: An interactive multimedia course of study. Rice University. Retrieved from http://onlinestatbook.com/Online_Statistics_ Education.pdf.

Lau, J. (2006). IFLA guidelines on informational literacy for lifelong learning. Retrieved from http://www.ifla.org/files/assets/information-literacy/publications/ifla-guidelines-en. pdf.

Leebaw, D., Partlo, K., \& Tompkins, H. (2013). How is this different from critical thinking? The risks and rewards of deepening faculty involvement in an information literacy rubric. ACRL, 2013, 274-277.

McCracken, M., \& Johnson, B. (2015, September 25). Sustainable partners: Librarians and instructors using threshold concepts to reinforce information literacy. Paper presented at Georgia International Conference on Information Literacy. 40, Retrieved from http:// digitalcommons.georgiasouthern.edu/gaintlit/2015/2015/40.

Ortega, S., \& Stewart, K. (2014). Report from the UNC General Education Council. Chapel Hill: Committee on Educational Planning, Policies, and Programs. University of North Carolina Retrieved from http://assessment.uncg.edu/academic/GenEd/ documents/2014-01\%20UNC\%20GEC\%20Report.pdf.

Samson, S. (2010, May). Information literacy learning outcomes and student success. The Journal of Academic Librarianship, 36(3), 202-210 Retrieved from http://www. sciencedirect.com/science/article/pii/S0099133310000595.

Scharf, D., Elliot, N., Huey, H. A., Briller, V., \& Joshi, K. (2007, July). Direct assessment of information literacy using writing portfolios. Journal of Academic of Librarianship, 33(4),
462-477 Retrieved from http://www.sciencedirect.com/science/article/pii/ S0099133307000870.

Soleymani, M. Z. (2014). Investigating the relationship between information literacy and academic performance among students. International Journal of Health Promotion and Education, 3 Retrieved from http://www.ncbi.nlm.nih.gov/pmc/articles/ PMC4165104/.

Soria, K. M., Fransen, J., \& Nackerud, S. (2014). Stacks, serials, search engines, and stu dents' success: First-year undergraduate students' library use, academic achievement, and retention. The Journal of Academic Librarianship, 40(1), 84-91 Retrieved from http://www.sciencedirect.com/science/article/pii/S0099133313001560.

Thompson, M. S. (2013, April 10). Melding the nitty gritty of critical thinking and information literacy into English developmental and composition classes. Paper presented at ACRL Conference, April 10-13, 2013, Indianapolis, Indiana Retrieved from http:// www.ala.org/acrl/sites/ala.org.acrl/files/content/conferences/confsandpreconfs/ 2013/papers/Thompson_Melding.pdf.

Vance, J. M. Kirk, R., \& Gardner, J. G. (2012). Measuring the impact of library instruction on freshman success and persistence. Communications in Information Literacy, 6(1), 49-58 Retrieved from http://www.comminfolit.org/index.php?journal=cil\&page= article\&op=view \&path $\% 5 \mathrm{~B} \% 5 \mathrm{D}=\mathrm{v} 6 \mathrm{i1p} 49 \& p a t h \% 5 \mathrm{~B} \% 5 \mathrm{D}=144$.

Wertz, R. E. H., Fosmire, M., Purzer, S., Sragih, A. I., Van Epps, A. S., Sapp Nelson, M. R., \& Dillman, B. G. (2013). Work in progress: Critical thinking and information literacy: Assessing student performance. Proceedings of the 120th ASEE conference. Washington D.C.: American Society for Engineering Education Retrieved from http://www.asee.org/public/conferences/20/papers/6925/view.

White-Farnham, J., \& Gardner, C. C. (2014). Crowdsourcing the curriculum: Information literacy instruction in first-year writing. Reference Services Review, 42(2), 277-292.

Zhong, Y., \& Alexander, J. (2007, March 29). Academic success: How library services make difference. Paper presented at ACRL Thirteenth National Conference, March 29-April 1, 2007, Baltimore, Maryland. (pp. 141-148). 